suffering from Brocq's congenital ichthyosiform erythroderma, was washed with the soap, when the collodion-like layer was separating off, without harmful reaction.

\section{Miscellaneous Cases}

This small group includes three cases of palmar toxic bacteride and two of keratoderma climactericum with deep palmar fissuring. None showed any retrogression which could be attributed to washing with the soap. Two patients with facial pigmentation (melanosis) which was thought to be due to scented cosmetics were much improved when allowed to use this soap, and avoiding the cosmetics. Four cases of genital and anal pruritus associated with inflammation, whilst receiving local therapy, used the neutral soap for cleansing without adverse effect.

\section{Conclusions}

From the clinical aspect it can be concluded that this neutral soap is a most useful addition to the armamentarium of dermatological practice. It would seem to prevent excessive denaturing of the normal skin, and can be used with confidence in cases of subacute eczema. Furthermore, in the few cases of acute and secondarily infected eczema it was well tolerated.

It would be imprudent to cite statistical evidence in appraisal of this soap, when the trial consisted of a comparatively small number of selected cases. There are also many psychological factors involved, such as the clinician's enthusiasm, the patients' delight in being allowed to wash normally, and perhaps the novelty of receiving a free sample of an imported soap. Furthermore, apart from ward cases and clinical observation, most of the evidence came from the patients themselves. In some of the new patients the prescribing of topical hydrocortisone for the first time often made the general progress more rapid, and with this the patient's morale improved on the treatment as a whole.

In spite of these and other factors, however, clinical observation confirmed that the soap was well tolerated by patients with eczema and xeroderma. The fact that most patients continued to purchase this not inexpensive soap (whereas cleansing emulsions were supplied free) speaks for the joy afforded them by its use. When unilateral control was possible, it seemed superior to cleansing emulsions. A control using ordinary alkaline soap was not deemed justifiable in the interests of the patients.

\section{Summary}

The properties of a neutral soap have been investigated in the laboratory and in hospital.

After the skin had been washed with the soap, the skin-fat factor showed no change from the normal, and the $p \mathrm{H}$ of the skin remained unaltered. Thus its use did not involve any denaturing of the skin, and its protective acid mantle remained intact.

Clinically it was found to be innocuous to persons who found the excessive use of ordinary toilet soap to be detrimental to skin health. Furthermore, about 100 patients suffering from subacute eczema, who would normally be forbidden to wash with soap, were able to enjoy using this neutral soap with impunity.

We are indebted to Messrs. M. and R. Norton Ltd., Adriant Works, London, S.W.4, for kindly supplying samples of "neutrogena" soap. We thank Miss J. Wylie for technical assistance, and the nursing staffs of the various hospitals concerned for their ready co-operation.

\section{REFERENCES}

Anderson, D. S. (1951). Brit. J. Derm., 63, 283.

Anderson, D. S. (1954). Bri. J. Der., 63, 283.894

Chiego, B., and Silver, H. (1942). J. invest. Derm., 5, 95.

Jambor, J. J. (1955). Ibid., 24, 387

Klauder, J. V and Gross, B. A (1951), A.M.A Arch Derm, 63,

Lyon. J. B. (1954). Brit. J. Derm. 66, 308

Morris, G. E. (1953). Arch. industr. Hyg., 7,411

Ramsay, A. G.. and Jones, K. K. (1955). Brit. J. Derm. 67,

Schwartz, B. (1954). Med. ill. (Lond.) 8, 674

Van Scott, E. J., and Lyon, J. B. (1953). J. invest. Derm., 21, 199.

\section{LIVER FUNCTION IN KWASHIORKOR}

BY

\section{A. A. KINNEAR, M.D.}

AND

\section{P. J. PRETORIUS, M.Med.(Paed.)}

From the Departments of Chemical Pathology and Paediatrics, University of Pretoria Medical School, Pretoria, South Africa

Kwashiorkor is generally accepted as a protein-deficiency syndrome. Since the pioneer work of Trowell (1939) and Cofino and Klee (1942) several workers in Africa have reported on the serum protein spectrum in kwashiorkor (Altmann, 1948, 1953; Janssen and le Roux, 1950 ; Walt et al., 1950 ; Gillman and Gillman, 1951 ; Anderson and Altmann, 1951). Altmann (1953) reported on the thymol turbidity and flocculation tests in 20 cases of $\mathbf{k w a s h i o r k o r . ~ H e ~ c o u l d ~ f i n d ~ n o ~ p r o g n o s t i c ~}$ or diagnostic value for the tests in kwashiorkor. The bromsulphthalein test gave positive results in three out of six cases, and Altmann could find no correlation between dye retention and fat content of the liver.

In the West Indies, Waterlow (1948) found normal values for alkaline phosphatase and serum colloidal gold. Serum bilirubin was slightly raised in only very severe cases of the disease. A high degree of correlation was found between bromsulphthalein retention and severity of the disease. Waterlow (1950), using the Cartesian diver technique, also found a significant depression of pseudocholinesterase in liver biopsies from cases of " fatty liver disease." Gómez et al. (1952) found that an abnormal thymol test with a normal cholesterol flocculation test is "a phenomenon seen with significant frequency in cases of malnutrition or pellagra in which it is not possible to detect any infection." On the other hand, they suggested that the finding of positive thymol and cephalin tests together was indicative of infection.

At Kampala, Dean and Schwartz (1953) found reduced esterification of cholesterol as well as a reduced pseudocholinesterase value in kwashiorkor. Values for alkaline phosphatase were low for the particular group. The serum protein pattern found by these workers compared well with that of other workers. In Curaçao, Van der Sar (1951) estimated the A:G ratio and the bromsulphthalein retention in 16 cases. Using a dose of $5 \mathrm{mg}$. per $\mathrm{kg}$. and a 30-minute interval, he found retention of dye in only five cases. His results for 16 total cholesterol and 13 ester estimations were normal. Total lipids in serum were estimated in 16 cases and found to be high. The normal cholesterol esters found by Van der Sar are in striking contrast to the defective esterification found by Dean and Schwartz (1953).

We report the results of liver-function tests carried out on 107 consecutive cases of kwashiorkor treated in the Pretoria Hospital. Bromsulphthalein retention was estimated in 51 cases. There were 19 fatal cases.

\section{Materials and Methods}

Blood was withdrawn from the external jugular vein in all cases before treatment was started. The tests were completed within 24 hours of drawing the blood.

Treatment consisted of various high-protein diets with or without added vitamins. The composition of the diets and the clinical data have been published by Brock et al. 
(1955). In a further report (Kinnear and Pretorius, 1956) the effect of the high-protein diets on serial liver-function tests will be described. The results of the liver-function tests in fatal kwashiorkor will be discussed in a later paper.

Serum Proteins.-Total serum proteins were estimated after the method of Weichselbaum (1946). Globulins were precipitated with $27.2 \%$ sodium sulphate and packed in the centrifuge with the aid of ether. An aliquot of the albumin solution was treated with Weichselbaum's biuret reagent. Both total protein and albumin were read in a spectrophotometer at 5,550 $\AA$ against appropriate blanks. Standardized bovine albumin was used as reference standard.

Thymol Turbidity.-The buffer was the standardized buffer of De la Huerga and Popper (1949). The turbidity was read in an Evelyn colorimeter calibrated with copper sulphate after the method of Ducci (1947a). A standardized buffer of $p \mathrm{H} 7.72$ was used, with 5 units on the copper sulphate scale the upper limit of normal. As a result of differences in sensitivity of batches of thymol reagent made by different methods, confusion has arisen in assessing normal limits (Mateer et al., 1947 ; Maclagan, 1944b ; De la Huerga and Popper, 1949 ; Katz et al., 1954).

Thymol Flocculation.-After the turbidity was read the solution was poured into test-tubes and left undisturbed overnight. Flocculation was graded $0-4+$.

Serum Colloidal Gold and Serum Colloidal Red.-The methods of Maclagan (1946) and of Ducci (1947b) respectively were followed.

Serum Bilirubin.-The method of Powell (1944) was followed because of the smaller amount of serum needed and the greater intensity of colour in the lower ranges.

Bromsulphthalein Retention.-A dose of $5 \mathrm{mg}$. per $\mathrm{kg}$. was used with a 45-minute interval. Bromsulphthalein was measured spectrophotometrically after the method of Gaebler (1945).

\section{Results}

The values for the tests are given in Table $I$.

Serum Proteins.-Total serum protein levels have been the most studied entity in severe kwashiorkor. Methods used have varied from Kjeldahl procedures to simple specific

TABLE I.-Liver-function Tests in Kwashiorkor before Treatment



TABLE II.-Serum Proteins in Kwashiorkor (g. protein per $100 \mathrm{ml}$. serum). Results Obtained by Various Authors using Chemical Methods

\begin{tabular}{|c|c|c|c|c|}
\hline Authors & $\begin{array}{l}\text { No. of } \\
\text { Estima- } \\
\text { tions }\end{array}$ & $\begin{array}{c}\text { Total } \\
\text { Protein } \\
\text { (Mean and } \\
\text { Range) }\end{array}$ & $\begin{array}{l}\text { Albumin } \\
\text { (Mean } \\
\text { and } \\
\text { Range) }\end{array}$ & $\begin{array}{l}\text { Globulin } \\
\text { (Mean } \\
\text { and } \\
\text { Range) }\end{array}$ \\
\hline Altmann (1948) & 20 & $\begin{array}{c}4 \cdot 20 \\
(2 \cdot 81-5 \cdot 98)\end{array}$ & $\begin{array}{c}2 \cdot 1 \\
(0 \cdot 85-3 \cdot 5)\end{array}$ & $\begin{array}{l}2 \cdot 1 \\
(1 \cdot 4-3 \cdot 5)\end{array}$ \\
\hline $\begin{array}{ccc}\underset{(1950)}{\text { Janssen }} \text { and } & \text { le } & \text { Roux } \\
, " & " & \end{array}$ & $\begin{array}{l}18 \\
23\end{array}$ & $\begin{array}{c}4 \cdot 07 \\
(3 \cdot 12-5 \cdot 12) \\
4 \cdot 20 \\
(3 \cdot 04-6 \cdot 09)\end{array}$ & $\begin{array}{c}1.98 \\
(1 \cdot 30-2 \cdot 65) \\
2.09 \\
(1 \cdot 42-3 \cdot 57)\end{array}$ & $\begin{array}{c}2.09 \\
(1 \cdot 37-3.49) \\
2 \cdot 11 \\
(0 \cdot 50-3 \cdot 79)\end{array}$ \\
\hline Van der Sar (1951) $\ldots$ & 31 & & $\overline{7}$ & $\overline{\overline{01}}$ \\
\hline$\underset{(1953)}{\operatorname{Dean} \underset{n}{0} \text { Schwartz }} \cdots$ & $\begin{array}{l}16 \\
33\end{array}$ & $\begin{array}{c}4 \cdot 17 \\
3 \cdot 98 \\
(2 \cdot 90-5 \cdot 10)\end{array}$ & $\stackrel{2 \cdot 16}{-}$ & 2.01 \\
\hline " $\quad$. & 18 & - & $\begin{array}{c}1.51 \\
(0.76-2 \cdot 17)\end{array}$ & $\stackrel{2 \cdot 44}{(1.68-3.62)}$ \\
\hline Achar and Benjamin & 40 & $\begin{array}{c}4 \cdot 38 \\
(2 \cdot 81-5 \cdot 98)\end{array}$ & $\begin{array}{c}2.19 \\
(0.85-3.98)\end{array}$ & 2.19 \\
\hline $\begin{array}{c}\text { Kinnear and Pretorius } \\
(1956)\end{array}$ & 107 & $\begin{array}{c}3 \cdot 74 \\
(2 \cdot 90-5 \cdot 38)\end{array}$ & $\begin{array}{c}1.55 \\
(0.91-2 \cdot 44)\end{array}$ & $\begin{array}{l}2 \cdot 20 \\
(1 \cdot 53-3 \cdot 25)\end{array}$ \\
\hline
\end{tabular}

gravity methods. Table II summarizes the results obtained by various authors. A striking feature is the similarity of results reported by different workers. It would appear that in outspoken kwashiorkor the total serum protein is depressed to about $4 \mathrm{~g}$. per $100 \mathrm{ml}$., while the albumin fraction is depressed to about $1.5-2 \mathrm{~g}$. per $100 \mathrm{ml}$. Greater disparity among the albumin values could be anticipated because of the diversity of fractionation procedures. $23 \%$ sodium sulphate, which is often used, is prone to overestimate the albumin value. Anderson and Altmann (1951), using free electrophoresis, found an albumin concentration of $1.53 \mathrm{~g}$. per $100 \mathrm{ml}$. and a globulin concentration of $2.47 \mathrm{~g}$. per $100 \mathrm{ml}$. These results are strikingly close to our chemical method of estimation of $1.55 \mathrm{~g}$. of albumin per $100 \mathrm{ml}$. and $2.2 \mathrm{~g}$. of globulin per $100 \mathrm{ml}$. In results to be published from this laboratory (Kinnear, 1956) the results of Anderson and Altmann will in the main be confirmed by free Tiselius runs on 56 sera.

Thymol Turbidity and Thymol Flocculation.-From the results in Table I it can be seen that there is no overall abnormality as indicated by the thymol turbidity test. In $7 \%$ of all cases elevated thymol values were obtained, but no correlation could be found between severity of the disease and the thymol turbidity or flocculation tests. This would agree with Altmann (1953), who stated that "the thymol test has no diagnostic or prognostic value in kwashiorkor." These findings do not agree with those of Dricot, Behegt, and Charles (quoted by Brock and Autret, 1952), who found " severe liver deficiency determined by the following tests : Quick's tests, Takata-Ara, thymol turbidity, serum bilirubin, hippuric acid test, B.S.P. test." No further information is given. Altmann (1953) had 10 positive thymol tests in a series of 25 cases; none of these became negative after clinical cure; in fact, another 10 cases became positive where they were initially negative.

In our series of 107 cases $21 \%$ of clinically cured cases showed a thymol test which had changed from negative to positive at initiation of clinical cure. In a further $11 \%$ of clinically cured cases the thymol test was positive throughout the illness. As mentioned earlier the second part of this investigation was to test the effect of various high-protein diets on serial liver-function tests. For this reason blood was collected at three-day intervals. The clinical course of the disease in response to different high-protein diets has already been described (Brock et al., 1955). It was found that $36 \%$ of cases in which the thymol test was normal on admission showed a marked rise in thymol values between the 3rd and the 15 th day after treatment. On the patient's discharge these values had become normal again. Of those cases which were positive on admission but negative on discharge, $30 \%$ showed an increase in thymol values during the same 3- to 15-day period; they then fell to within normal limits on discharge. The same rise in values during the 3 rd to 15 th days was observed with those cases which had an abnormal thymol test throughout their illness.

A combination of factors influence the protein flocculation tests (Maclagan, 1944b, 1946, 1948 ; Moore et al., 1945; Recant et al.. 1945 ; Cohen and Thompson, 1947 ; Hanger, 1946 ; Maclagan and Bunn, 1947 ; Kunkel and Hoagland, 1947 ; Ernst and Dotti, 1948 ; De la Huerga and Popper, 1949). Because of the yet unknown interplay of factors in the thymol test, it is not possible to explain this phenomenon. However, it has been shown (Kinnear and Pretorius, 1956) that overt cases of kwashiorkor almost invariably have low total serum lipids-these serum lipids rose during the same period that the thymol tests were abnormal and then tended to plateau again. However, this lipid pattern was common to all cases and not only to those cases which showed rising thymol values. The relation between lipid and positive thymol tests has already been noted. The thymol turbidity test would appear to have no diagnostic or prognostic significance in kwashiorkor.

Serum Colloidal Red and Serum Colloidal Gold.Maizels (1946) introduced a three-tube colloidal-red test as 
a substitute for the gold test of Maclagan. Ducci (1947b) modified the test to a one-tube method and used a buffer of $p \mathrm{H}$ 7.58. Maclagan (1944a) modified the serum colloidal gold test of Gray (1940). The mechanisms of these tests are similar and are discussed together. These tests were negative in 103 of the 107 cases. The four positive cases still showed positive gold and red tests on discharge along with an altered albumin/globulin ratio. Waterlow (1948) found essentially normal values for the serum colloidal gold reaction in the West Indies. These two tests did not show the fluctuations of the thymol test. No diagnostic or prognostic importance could be attached to these two tests.

Van den Bergh Reaction and Total Serum Bilirubin.In our series of 107 cases the van den Bergh reaction was always negative and the total serum bilirubin was always within normal limits.

Bromsulphthalein Retention.-Mateer et al. (1943), after a study of the problem, stated that "the 45 -minute period has been adopted, therefore, as the normal standard for complete disappearance of the dye after injection of $5 \mathrm{mg}$. of bromsulphthalein per $\mathrm{kg}$." This standard is far too stringent, and on the basis of work carried out in this laboratory $0-5 \%$ retention has been taken as normal. Waterlow (1948) found a high degree of correlation between severity of the disease and bromsulphthalein retention in a small series of cases. Dr. Dean, of Kampala, kindly drew my attention to an article by Tovar-Escobar and De Majo (1955), in which they performed bromsulphthalein tests in cases of Venezuelan kwashiorkor. They used a dose of $2 \mathrm{mg}$. per $\mathrm{kg}$. in 12 cases and found no abnormal retention. On increasing the dose to $5 \mathrm{mg}$. per $\mathrm{kg}$. they observed abnormal results in most of the very severe cases treated.

In our cases the average bromsulphthalein retention on admission was $15 \%$, with a standard deviation of 9.25 and a range of $2.4-40 \%$. In cases which recovered, the bromsulphthalein retention was usually normal within three days and at latest six days (four cases only). If the bromsulphthalein retention was still abnormal at one week the prognosis was grave and death ensued. We found no exception to this in 19 fatal cases of the disease. Comparison of the bromsulphthalein values three days after treatment in cases which recovered with the three-day values of fatal cases of the disease gave a $t$ of 6.02 . This is highly significarit. The bromsulphthalein test will be further discussed in a later paper (Kinnear and Pretorius, 1956).

\section{Summary}

A number of liver-function tests were performed on 107 cases of kwashiorkor.

The serum protein spectrum found compared well with previous chemical and electrophoretic separations.

The thymol test showed nothing of diagnostic or prognostic significance. A possible relation to the serum lipids was noted.

No diagnostic or prognostic value could be attached to the serum colloidal gold or serum colloidal red tests.

The van den Bergh reaction and the serum bilirubin were normal in all cases.

The bromsulphthalein test had marked prognostic significance. Abnormal retention at six days after treatment had begun was followed by death in all 19 cases studied. In cases which recovered, the bromsulphthalein test was normal three days after treatment had begun.

\section{REFERENCES}

Achar, S. T. and Benjamin, V. (1953). Indian J. Child Hlth, 2, 1. Altmann, A. (1948). Clin. Proc., 7, 32.

Anderson, C. G. Afr. J. clin. Sci., 4, 71.

Anderson, C. G., and Altmann, A. (1951). Lancet, 1, 203 68

Brock, J. F., and Autret, M. (1952). Bull. Wld Hith Org., 5, 68. Hansen, J. D. L., Howe, E. E., Pretorius,

Hendrickse, R. G. (1955). Lancet, 2, 355
Cohen, P. P., and Thompson, F. L. (1947). J. Lab. clin. Med., 32, 475.
Cofino, U. E., and Klee, G. A. (1942). Memoria del V Congresso Medico Centroamericano.

Dean, R. F. A., and Schwartz, R. (1953). Brit. J. Nutr. 7, 131.

De la Huerga, J., and Popper, H. (1949). J. Lab. clin. Med., 34, 877. Ducci, H. (1947a). Ibid., 32, 1266.

$32,1273$.

G. and Dotti, L. B. (1948). Amer. J. med. Sci., 216, 316 Gaebler, O. H (1945). Amer. J clin. Path $15,452$.

Gillman, $J$. H. (1945). Amer. J. clin. Path., 15, 452. Human Malnutrition. Grune and Stratton, New York.

Gómez, F., Galván, R. R., and Muñoz, J. C. (1952). Pediatrics, 10, 513. Gray, S. J.' (1940). Arch. intern. Med.. 65, 524

Hanger. F. M. (1946). Transactions of the Fifth Meeting of the Conference on Liver Injury. Josiah Macy Jr. Foundation, New York.

on Liver Injury. Josiah Macy J $\mathrm{r}$. Foundation, New York. 100.

Katz, E. J., Hasterlik, R. J., and Snapp, F. E (1954). J. Lab. clin. Med., 44, 353 .

Kinnear, A. A. (1956). In press.

- and Pretorius, P. J. (1956). In press.

Kunkel, H. G., and Hoagland, C. L. (1947). J. clin. Invest., 26, 1060.

Maclagan, N. F. (1944a). Brit. J. exp Path., 25, 15.

- (1944b). Ibid., 25, 234.

(1946). Ibid., 27, 369

1948). British Medical Journal, 2, 892.

and Bunn, D. (1947). Biochem. J., 41, 580

Maizels, M. (1946). Lancet, 2, 451.

Mateer, J. G., Baltz, J. I., Marion, D. F. and MacMillan, J. H. (1943).

Steele, H. H., Brouwer, S. W., and Colvert, J. R. (1947). Ibid., 133, 909 .

Moore, D. B., Pierson, P. S., Hanger, F. M., and Moore, D. H. (1945). J. clin. Invest., 24, 292.

Powell, W. N. (1944). Amer. J. clin. Path., 14, Tech. Sect. 55.

Recant, L., Chargaff, E., and Hanger, F. M 14, Tech. Sect. 55. $(N . Y), 60,245$.

Tovar-Escobar, G., and De Majo, B. L. (1955). Docum. med. Geogr. Trop., 7, 116 .

Trowell, H. C. (1939). Trans. roy. Soc. trop. Med. Hyg., 33, 389.

Van der Sar, A. (1951). Docum. neerl., indones. Morb. trop., 3, 25.

Walt, F., Wills, L., and Nightingale R. P. (1950). S. Afr. 'med. J., 24,

Waterlow, J. C. (1948). Spec Rep. Ser. med. Res. Coun. (Lond.), No. 263 Lancet $1,908$.

Weichselbaum, T. E. (1946). Amer. J. clin. Path., Tech. Suppl., 10, 40.

\section{Medical Memoranda}

\section{Treatment of the Cord in the Newborn}

Several methods of treating the umbilical cord of the newborn are in use at various centres, each having its own routine. In an attempt to discover which of a selection of these procedures is the safest, the following four were used for a trial in the maternity wards at Farnborough Hospital.

Methods.-(1) Traditional routine of treatment with spirit, powder, lint dressing, and binder. (2) Wharton's jelly first squeezed out, then as in No. 1. (3) No dressing applied, the only treatment being the daily application of spirit to the cord base. (4) Wharton's jelly first squeezed out, then as in No. 3.

Procedure.-Newborn babies were allocated to groups (1) to (4) consecutively, in the order of their admission to the nurseries-that is, the first infant was allocated to group 1, the next to group 2, and so on. The investigation was conducted independently on the upper and ground floors of the maternity block. Early in the trial a cord treated by method 3 became very badly infected with Bact. coli, and it was considered unsafe to continue this procedure. All neonates thereafter were treated by methods 1,2 , or 4 (see Table). This series covers a three-months period and is made up of 224 consecutive newborn babies admitted to the two general nurseries from the labour ward. Four babies had to be eliminated from the series, as they were taken home before their cords had separated.

\begin{tabular}{|c|c|c|c|c|c|}
\hline \multirow{2}{*}{ Method } & \multirow{2}{*}{ Floor } & \multirow{2}{*}{$\begin{array}{l}\text { No. of } \\
\text { Cases }\end{array}$} & \multirow{2}{*}{$\begin{array}{l}\text { Infected } \\
\text { Cords }\end{array}$} & \multicolumn{2}{|c|}{$\begin{array}{l}\text { Time Taken in Days for } \\
\text { Separation of Cord }\end{array}$} \\
\hline & & & & Average & Limits \\
\hline 1\{ & $\begin{array}{l}\text { Upper } \\
\text { Ground }\end{array}$ & $\begin{array}{l}42 \\
29\end{array}$ & - & $\begin{array}{l}7 \\
8\end{array}$ & $\begin{array}{l}4-10 \\
4-12\end{array}$ \\
\hline 2 & $\begin{array}{l}\text { Upper } \\
\text { Ground }\end{array}$ & $\begin{array}{l}38 \\
28\end{array}$ & 二 & $\begin{array}{l}71 \\
7 \frac{1}{8}\end{array}$ & $\begin{array}{l}4-11 \\
3-12\end{array}$ \\
\hline 3 & $\begin{array}{l}\text { Upper } \\
\text { Ground }\end{array}$ & $\begin{array}{l}9 \\
9\end{array}$ & 1 & $\begin{array}{l}9 \\
8\end{array}$ & $\begin{array}{l}6-11 \\
4-12\end{array}$ \\
\hline 4\{ & $\begin{array}{l}\text { Upper } \\
\text { Ground }\end{array}$ & $\begin{array}{l}38 \\
27\end{array}$ & 2 & $8 \frac{1}{2}$ & $\begin{array}{l}3-12 \\
4-14\end{array}$ \\
\hline
\end{tabular}

